\title{
First record of dance flies of the subgenus Anacrosticbus Bezzi (Diptera: Empididae) from the Caucasus, with description of a new species
}

\author{
Первая находка мух-толкунчиков подрода Anacrostichus Bezzi \\ (Diptera: Empididae) на Кавказе, с описанием нового вида
}

\author{
I.V. Shamshev \\ И.В. Шамшев
} Zoological Institute, Russian Academy of Sciences, Universitetskaya nab. 1, St. Petersburg 199034, Russia. E-mail: shamshev@mail.ru
Зоологический институт РАН, Университетская наб. 1, С.-Петербург 199034, Россия.

KEYWORDS. Diptera, Empididae, Empis, Anacrostichus, new species, Caucasus, Palaearctic.

КЛЮЧЕВЫЕ СЛОВА. Diptera, Empididae, Empis, Anacrostichus, новый вид, Кавказ, Палеарктика.

ABSTRACT. The subgenus Anacrostichus Bezzi, 1909 (Diptera: Empididae) is found from the Caucasus for the first time where it is represented by the single species, Empis (Anacrostichus) kustovi sp.n. (Georgia, Russia). A key to all European species of Anacrostichus is provided for the first time.

РЕЗЮМЕ. Подрод Anacrostichus Bezzi, 1909 (Diptera: Empididae) впервые отмечается с территории Кавказа, где он представлен единственным видом Empis (Anacrostichus) kustovi sp.n. (Грузия, Россия). Впервые подготовлена определительная таблица всех вид Anacrostichus Европы.

\section{Introduction}

The subgenus Anacrostichus Bezzi, 1909 (with Empis nitida Meigen, 1804 as type species) is a quite heterogeneous group of dance flies of the genus Empis Linnaeus, 1758. The precise definition of Anacrostichus is not easily stated and, like some other Empis subgenera, is more evident for males. This problem is beyond the scope of our paper and we refer to the broaden diagnosis of the subgenus provided by Chvála [1994]. Generally, species of Anacrostichus can be distinguished from other groups of Empis (at least in Europe) by the shape of the male postabdomen, which is foot-shaped with the terminalia placed in a more or less ventral position, modified pregenital sternites and funnel-like segment 8 .

Anacrostichus is mainly a Holarctic group but some undescribed species are known to the author from South America and the Oriental Region. Also, Anacrostichus is often the only representative of Empis occurring in subarctic latitudes. Currently, nine species of Anacrostichus are known from the Palaearctic, seven species (including a new one described here) are recorded from Europe. This paper provides the first record of Anacrostichus from the Caucasus. Also, a key to all European species of the subgenus is compiled for the first time.

\section{Material and methods}

This study is based on Empididae material housed in the Zoological Institute of Russian Academy of Sciences, St. Petersburg, Russia (ZIN), Zoological Museum of Moscow State University, Moscow, Russia (ZMMU) and Kubanskiy State University, Krasnodar, Russia (KSU). Pinned, dried specimens were studied. To facilitate observations, the terminalia were macerated in cold $10 \% \mathrm{KOH}$, then put for a short period in $85 \%$ lactic acid and immersed in glycerine. Terms used for adult structures primarily follow those summarised by Cumming et Wood [2009]. The holotype of the new species is housed in ZIN, and the paratypes as noted.

\section{Taxonomic account}

Class Insecta Linnaeus, 1758

Order Diptera Linnaeus, 1758

Suborder Brachycera Macquart, 1834

Superfamily Empidoidea Latreille, 1804

Family Empididae Latreille, 1804

Empis (Anacrostichus) kustovi Shamshev, sp.n. Figs 1-6.

TYPE MATERIAL: Holotype, $0^{7}$ labelled [printed in Cyrillic] [RUSSIA: Karachay-Cherkessia] Teberdinsk. zapov. [=Teberdinskiy zapovednik, $=$ Teberdinskiy Nature Reserve]/ Sev. Kavkaz ok. 2000 [=Severny Kavkaz okolo 2000m, =North Caucasus about $2000 \mathrm{~m}] /$ Gorodkov 3.ix.[1]965; okr. per. Chuchkhur $[=$ okrestnisti perevala Chuchkhur, =environs of pass Chuchkhur $] / 5 \mathrm{~km} \mathrm{~N}$ of

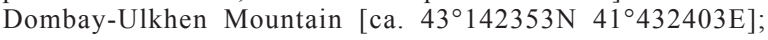
vysokotravie [=tall herbaceous cover]; HOLOTYPE [red]; Empis kustovi Shamshev (ZIN).

Paratypes: GEORGIA: $1 \overbrace{}^{\top}$, Marukh Mountain near Chkhalty

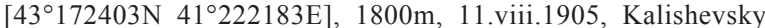

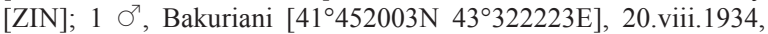
Kirshenblyat [ZIN]; 1 O$^{7}$, Bakurianka River above town, 9.vii.1953, Zhiltsova [ZIN]; 2 우, Bakuriani, Bakurianka River, 3.viii.1953, Zhiltsova [ZIN]. RUSSIA: Adygea: $1 \sigma^{7}$, foot of Oshten Mountain

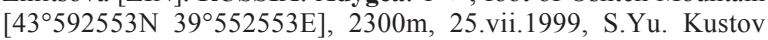
(KSU); Karachay-Cherkessia: $1 O^{7}, 2$ ++ , same data as in holotype 
(ZIN); 1 ㅇ, Teberdinskiy Nature Reserve, Severny Priyut, subalpine tall herbaceous cover, 2000-2200m, 29.viii.1965, Gorodkov (ZIN) $2 \bigcirc^{7} \sigma^{7}, 1$, Teberdinskiy Nature Reserve, Klukhorskoe Lake, $2700 \mathrm{~m}$, alpine meadow, 29.viii.1965, Gorodkov (ZIN); 1 우 , Teberdinskiy Nature Reserve, Klukhorskiy Pass $\left[43^{\circ} 142393 \mathrm{~N}\right.$

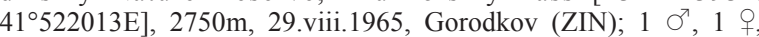
Teberdinskiy Nature Reserve, Malaya Khatipara Mountain

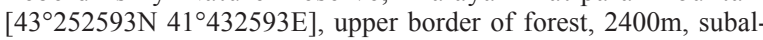
pine meadow, 9.vii.1968, Gorodkov (ZIN); $10^{7}, 1$, Klukhor River

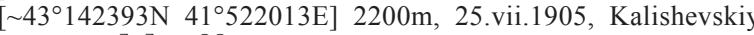

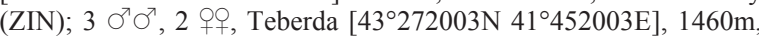
16.vii.1965, N. Lapshina (ZMMU); $1 \sigma^{7}$, Teberda, 1460m, 17.vii.1965, N. Lapshina (ZMMU); 1 ○', Teberda, Klulhori Lake, 11.viii.1965, N. Lapshina (ZMMU); Krasnodarskiy Territory: 4 $\sigma^{\top} \sigma^{\top}$, Sochinskiy District, Caucasian Biosphere Reserve, environs

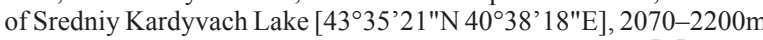
a.s.1., 4.viii.2010, S.Yu. Kustov, V.V. Gladun (KSU); $3 \sigma^{7} \sigma^{7}$, Sochinskiy District, Caucasian Biosphere Reserve, environs of Kardy-

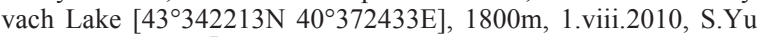
Kustov (KSU); $1 \mathrm{O}^{7}$, same locality, 2.viii.2010, S.Yu. Kustov (KSU);
$9 \bigcirc^{7} \bigcirc^{7}$, Maykopskiy District, Caucasian Biosphere Reserve, Abago Ridge $\left[\sim 43.90^{\circ} \mathrm{N} 40.15^{\circ} \mathrm{E}\right], 2100 \mathrm{~m}$, near snowfield, 4.viii.2008, S.Yu. Kustov (KSU); $1 O^{7}$, same locality, 3.viii.2008, V.V. Gladun (KSU).

DIAGNOSIS. Large black strongly bristled species, $\sigma^{7}$ eyes dichoptic, frons narrow on upper part; antenna and palpus black; scutum densely pollinose with brownish vittae along dorsocentral and, less distinct, acrostichal setal rows; laterotergite with black setae; legs blackish brown, hind femur not thickened; abdominal sternite 5 with rows of numerous black, spine-like bristles on each side.

DESCRIPTION. Male (Fig. 1). Head black in ground colour, with black setation. Eyes dichoptic; ommatidia of equal size. Frons narrow on upper part, 1.5-2 times broader than anterior ocellus but broadened above antennae; densely brownish pollinose, with marginal setulae. Face considerably broader than frons above antennae, somewhat broadened downwards, bare, densely greyish pollinose but clypeus sub-

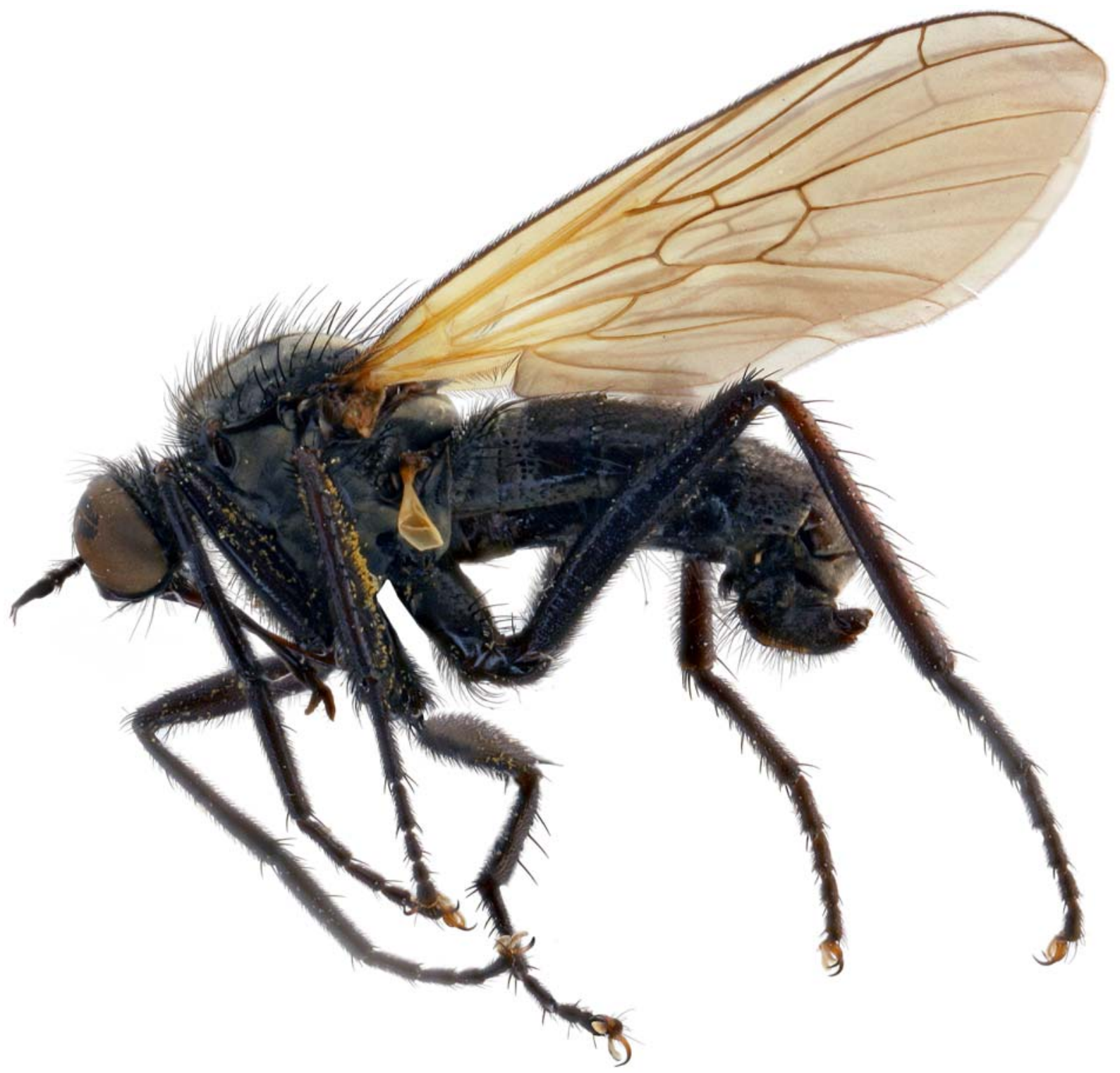

Fig. 1. Empis (Anacrostichus) kustovi sp.n., $0^{7}$, habitus, lateral view.

Pис. 1. Empis (Anacrostichus) kustovi sp.n., габитус самца, вид сбоку. 


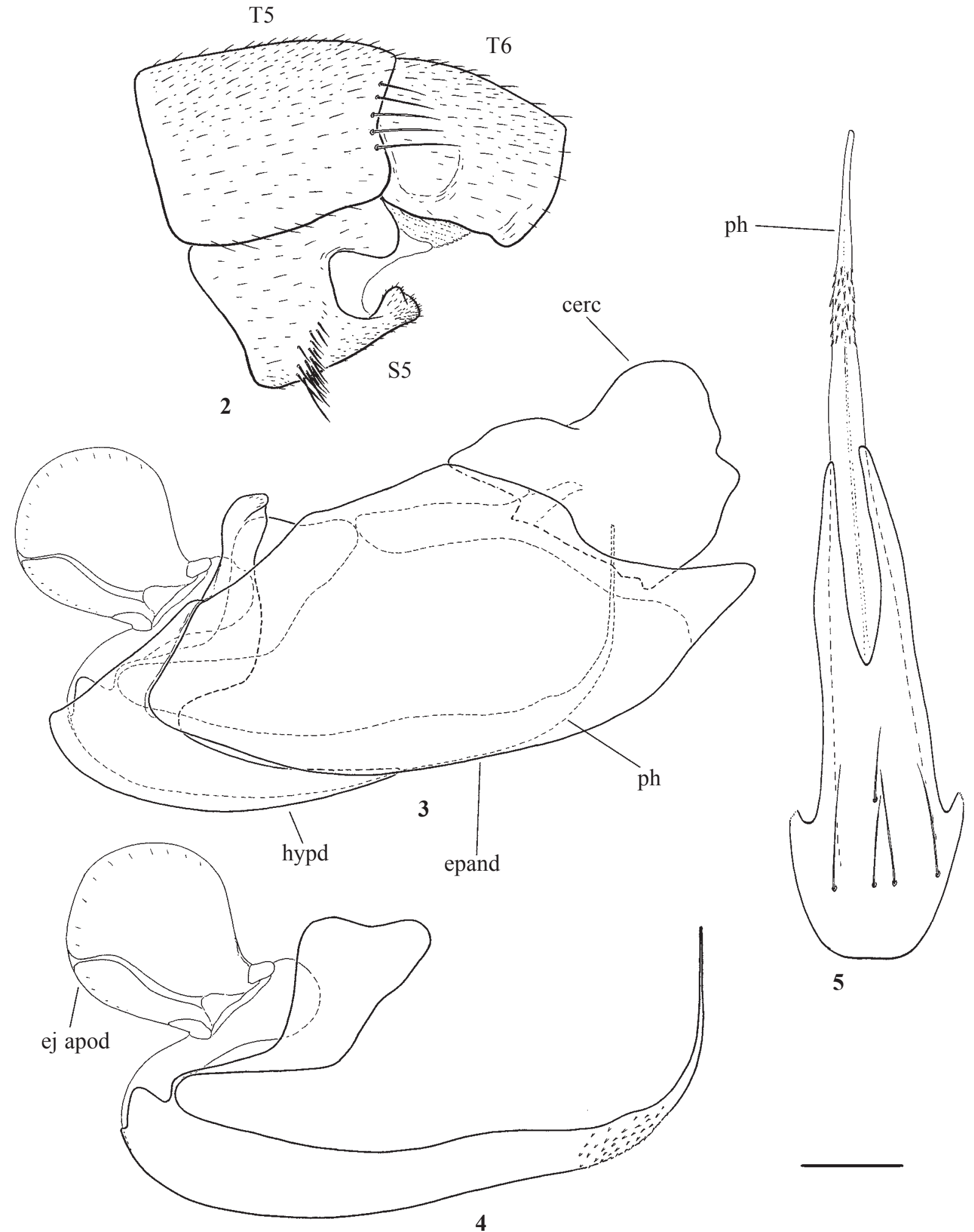

Figs 2-5. Empis (Anacrostichus) kustovi sp.n., O': 2 - proximal portion of postabdomen, lateral view; 3 - terminalia, lateral view; 4 - phallus, lateral view; 5 - hypandrium, ventral view. Abbreviations: cerc — cercus; ej apod — ejaculatory apodeme; epand — epandrium; hypd - hypandrium; ph — phallus; T5 - tergite 5; T6 - tergite 6; S5 - sternite 5. Scale bar: $0.1 \mathrm{~mm}$.

Рис. 2-5. Empis (Anacrostichus) kustovi sp.n., самец: 2 - проксимальная часть постабдомена, сбоку; 3 - терминалии, сбоку; 4 — фаллус, сбоку; 5 — гипандрий, снизу. Сокращения: cerc — церк; еј ароd — эякуляторная аподема; ераnd — эпандрий; hypd — гипандрий; $\mathrm{ph}$ - фаллус; T5 - 5-й тергит; Т6 - 6-й тергит; S5 - 5-й стернит. Масштаб: 0.1 мм. 
shiny. Ocellar tubercle with several short to moderately long thin setae. Occiput densely light greyish pollinose with numerous strong setae of different lengths and some bristly hairs behind mouth-opening. Antenna black; scape about 1.5 times longer than pedicel; both with short setulae; postpedicel conical, with equally straight margins, rather long, 3.54.0 times longer than wide; stylus short, nearly one-third as long as postpedicel. Labrum brownish, nearly 1.5 times as long as head height. Palpus black, with several long and short black setae.

Thorax black in ground-colour, with black setation, largely uniformly densely greyish pollinose. Scutum with quite distinct narrow brownish vittae beneath dorsocentral setae disappearing just before prescutellar depression and with some traces of similar vitta beneath acrostichal setae. First cervical sclerite bare. Prosternum bare. Proepisternum with tuft of numerous long setae on lower portion and several similar setae on upper portion. Antepronotum convex, with numerous, irregularly placed, moderately long, strong setae. Postpronotal lobe with numerous moderately long setae, 1-2 setae usually somewhat longer. Mesonotum with 2-3 presutural supra-alars (1 seta always longer), 6-9 long notopleurals (patterns often asymmetrical on right and left sides of body), 3-4 postsutural supra-alars, 2-4 postalars (usually 2 and 1 seta always longer) and 3 pairs of subequally long scutellars (sometimes 4 pairs but then additional setae shorter and thinner); dorsocentrals represented by intermixed long, strong and shorter setae, arranged in 3 irregular rows anteriorly, becoming uniserial on prescutellar depression, prescutellar longest; acrostichal setae shorter and thinner than dorsocentrals, arranged in 2 irregular rows, present on prescutellar depression. Laterotergite with numerous black setae of different lengths. Anterior and posterior spiracles brown.

Legs quite robust, entirely blackish brown, with black setation; coxae and trochanters densely greyish pollinose, with ordinary setae. All podomeres with circlet of short to moderately long bristles. Fore femur with short dense anteroventral and posteroventral setae, but almost bare ventrally; several short strong anteroventral bristles closer to apex. Fore tibia with 3-4 moderately long anterodorsal and 3-4 posterodorsal bristles (length, robustness, number and position varying). Fore basitarsus slender, with ordinary setation (except circlet of subapicals). Mid femur with short spine-like anteroventral and somewhat longer similar posteroventral setae throughout, covered with dense spinule-like setulae ventrally. Mid tibia with 4-5 anterodorsal and 4-5 posterodorsal moderately long bristles (variations as in fore tibia), bearing 2-3 short anteroventral bristles. Mid basitarsus with 3 short anteroventral and 3 similar posteroventral bristles. Hind femur not thickened, nearly as broad as fore and mid femora; with row of short spine-like anteroventral setae on apical half and several similar bristles on subapical part anteriorly, covered with denser setulae ventrally. Hind tibia slender, with 5 anterodorsal, 5 posterodorsal and 1-2 dorsal bristles near extreme base (variations as in preceding femora), no bristle in comb. Hind basitarsus slender with several short anterodorsal and posterodorsal bristles. Pulvilli and claws long.

Wing faintly uniformly brownish infuscate; veins largely brownish, yellowish on basal part; complete (except Sc), well sclerotised. Two strong closely set costal bristles present (anterior longer). Pterostigma indistinct, very narrow. Veins $\mathrm{R}_{4+5}$ and $\mathrm{M}_{1}$ divergent toward wing-margin. Radial fork broad (somewhat varying), vein $\mathrm{R}_{4}$ straight to somewhat curved, vein $R_{5}$ meeting costa before wing-tip. Distance between veins $R_{4}$ and $R_{5}$ about 2.0 times longer than that between veins $\mathrm{R}_{4}$ and $\mathrm{R}_{2+3}$. Cell $\mathrm{dm}$ short. Anal angle very acute, anal lobe well developed. Calypter yellow, dark fringed. Halter yellow.

Abdomen black, with black setation; dorsum extensively shiny, but tergites 1,6 and 7 entirely densely greyish pollinose (tergites 6 and 7 with some golden brownish tinge), tergite 2 narrowly pollinose anteriorly and laterally, tergites 3-5 narrowly pollinose laterally, tergite 8 rather subshiny; sternite 2 pollinose medially, sternite 5 narrowly pollinose posteriorly, sternites 3-4 entirely shiny; tergite and sternite 8 rather subshiny. Tergites $1-5$ with long posteromarginal setae laterally in addition to short setae; tergites 6 and 7 almost bare, with some minute setulae laterally; tergite 8 with numerous moderately long setae. Sternites 1-4 with several long setulae medially, sternite 8 covered with numerous long setae. Sternites 5-7 modified; sternite 5 (Fig. 2) with rows of numerous black spine-like bristles on each side. Terminalia (Figs 3-5) dark brown (except yellow phallus); cercus (Fig. 3) small, unilobed, rather subrectangular, shiny, with scattered minute setae; epandrial lamella subtriangular with somewhat attenuated apex, faintly greyish pollinose, with numerous black setae longer along lower margin; phallus (Fig. 4) long, evenly curved and thin on about apical fourth, otherwise rather thick, with field of numerous spinules on subapical part; hypandrium (Fig. 5) deeply concave apically, with 5 moderately long bristles on basal part, shiny.

MEASUREMENTS. Body 8.1-8.7 (holotype 8.4) mm; wing 8.3-8.8 (holotype 8.5) $\mathrm{mm}$.

Female. Frons narrow, below ocellar tubercle only about 2 times broader than in $\sigma^{7}$, widened toward antennae. Occiput and palpus with shorter setae. Thorax and legs with shorter setation than in $\sigma^{7}$. Legs with ordinary setae, hind tibia brownish yellow near base. Abdomen with unmodified sternites, extensively shiny, only entire tergite 1 , tergites $2-5$ narrowly anteriorly and laterally, and sternites $4-5$ narrowly anteriorly greyish pollinose; cercus long, slender, with minute setae. Otherwise as in $0^{7}$.

MEASUREMENTS. Body $8.1-8.5 \mathrm{~mm}$; wing $8.0-8.4$ $\mathrm{mm}$.

DIFFERENTIAL DIAGNOSIS. Empis kustovi sp.n. is most similar to E. lucida Zetterstedt, 1838 differing primarily by the entirely densely pollinose scutum with three more or less distinct brownish vittae (four polished vittae in E. lucida).

ETYMOLOGY. The new species is named after Russian dipterist Semen Kustov (Krasnodar), who collected part of material used in this study, and in recognition of his contribution to the knowledge of Caucasian empidoids.

DISTRIBUTION. Palaearctic: Georgia, Russia (Adygea, Karachay-Cherkessia, Krasnodarskiy Territory) (Fig. 6).

HABITAT AND SEASONAL OCCURRENCE. This species inhabits alpine meadows, from the end of July until the beginning of September. The presence of pollen on the body of several specimens suggest that the new species is an active flower-visitor like other species of Anacrostichus. One male is pinned together with a large Bibionidae prey.

\section{Discussion}

According to label data the new species occurs in alpine areas of the high mountains of the Caucasus between 1460$2200 \mathrm{~m}$. Similar habitats has been known for central European E. monticola Loew, 1868, which is found only in the Alps. Empis kustovi sp.n. is possibly endemic to the Caucasus. However, we are unable to conclude whether the Caucasian population of E. kustovi sp.n. is a relict of a previously 


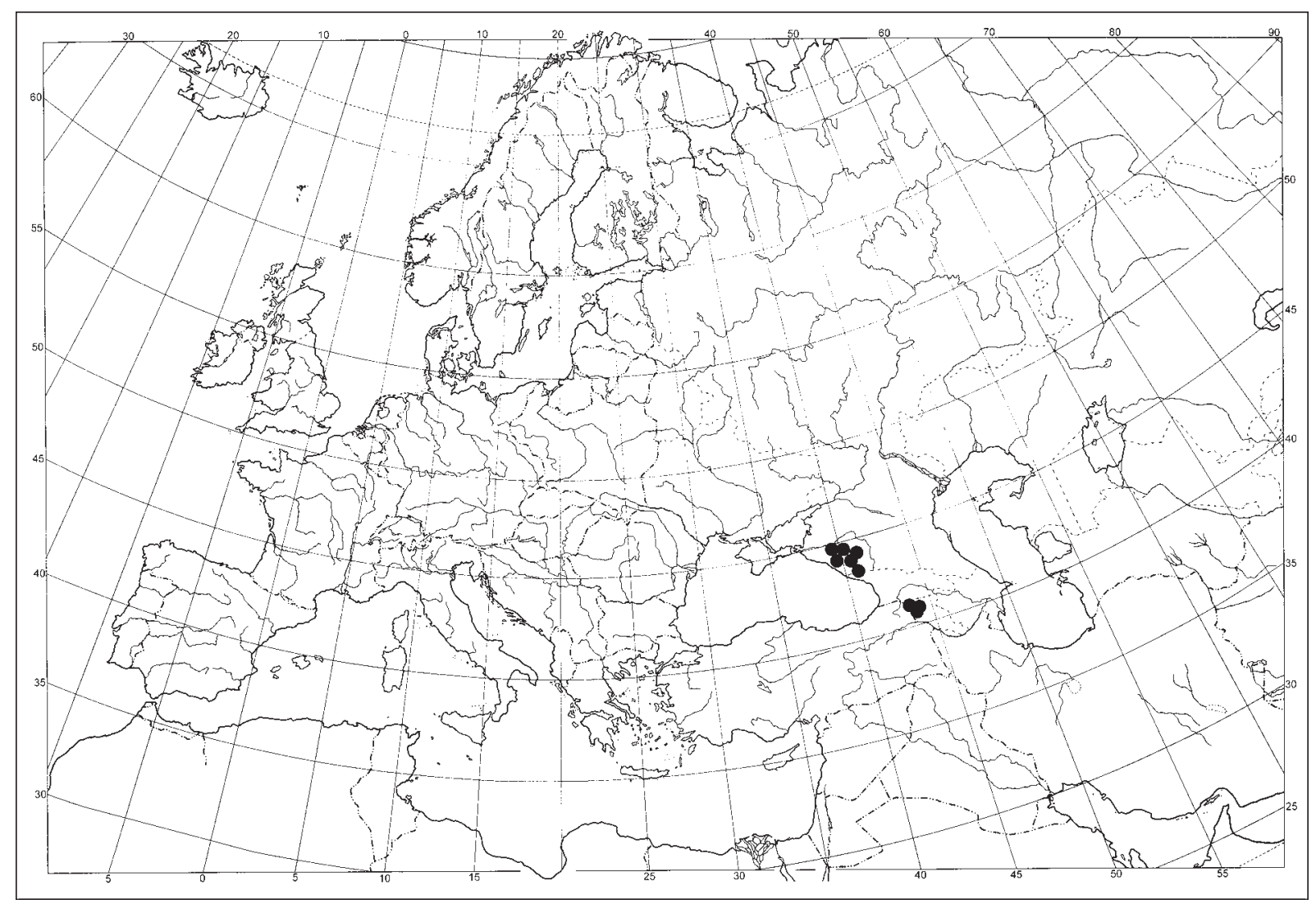

Fig. 6. Distribution of Empis (Anacrostichus) kustovi sp.n. in the Palaearctic Region.

Рис. 6. Распространение Empis (Anacrostichus) kustovi sp.n. в Палеарктическом регионе.

broader distribution affected by glaciations or a result of local speciation. Empis monticola is probably an example of the latter case. Chvála [1994] divided Anacrostichus into two species groups and E. kustovi sp.n. belongs to his E. lucida group. The phylogenetic relationships of Anacrostichus have not been resolved, but I would assume that E. kustovi sp.n. is somewhat intermediate between E. lucida and E. bistortae Meigen, $1822+$ E. monticola.

Concerning distributions of other European species of Anacrostichus, E. bistortae is a solely European species extending west to Portugal and Spain, but extreme eastern records refer only to the Carpathians (Ukraine); E. nitida has similar distribution, however, this species penetrates farther to the east, but only along the Baltic area as far as the Republic of Karelia and Leningradskaya Province of Russia; E. lucida and E. verralli Collin, 1927 are Holarctic, the latter is common in Siberia and the Russian Far East; Empis pachymorion Frey, 1935 is also common in Siberia (especially in eastern part) and in the Russian Far East, but gradually disappearing towards the west, with a single record from the Ural Mountains (in this respect E. nitida and E. pachymorion, which phylogenetically are sister species, appear as vicariant species) [Chvála, 1994; Shamshev, 2016, and unpublished data].

Key to European SPECIES of the EMPIS SUBgENus ANACROSTICHUS BeZzi

The key provided below includes all species of Anacrostichus that are currently known from Europe. Basically, the stricture of the key follows that of Chvála [1994: 50], but, some characters were re-evaluated and corrected. Chvála noted for the $q$ of $E$. bistortae that " 4 th abdominal tergum with a large projection on each side" [1.c.: 50 (key) and 56 (description)]. However, tergite 4 is simple in the 9 of this species and large projections, actually, may refer to pleural sacs that are present and often (when extracted) are very distinctive in E. bistortae just between tergite and sternite 4 . 1. Acrostichal setae present

- Acrostichal setae absent ...................................................... 4

2 . Scutum entirely densely pollinose but with distinct narrow brownish vitta beneath row of dorsocentral setae, disappearing just before prescutellar depression and with some traces of similar vitta beneath the row of acrostichal setae. $\sigma^{7}$ : eyes distinctly separated with frons $1.5-2$ times broader than the anterior ocellus. + : frons narrower on upper part ............................ E. (A.) kustovi Shamshev, sp.n.

- Scutum with more or less distinctly polished vittae between dorsocentral and acrostichal setae. $O^{7}$ : eyes almost touching on frons. + : frons parallel sided .............................. 3

3. Larger, 6-8 mm long; hind femora with short black spinelike setae beneath. $\sigma^{\prime}$ : abdominal sternite 5 modified, with apical comb of black spine-like setae between two fingerlike lateral projections .......... E. (A.) lucida Zetterstedt

-Smaller, 4-5 mm long; hind femora clothed in hair-like setae only. $\sigma^{7}$ : abdominal sternite 5 unmodified, with simple setae ............................................ E. (A.) verralli Collin

4. Hind femur at most slightly thicker than fore and mid femora ......

5

Hind femur very thickened, much broader than slender fore and mid femora (hind leg raptorial) .

5. Palpus blackish with brown to yellowish brown tip. $0^{7}$ : abdominal tergite 6 extensively shiny, pollinose only 
along posterior margin. : : hind tibia slender; abdomen shiny E. (A.) bistortae Loew

- Palpus yellow. $\sigma^{7}$ : abdominal tergite 6 entirely greyish pollinose. + : hind tibia evenly thickened towards apex; abdomen extensively brownish grey pollinose, tergites 2 5 broadly shiny dorsally, tergite 6 narrowly shiny posteriorly, tergites $7-8$ entirely shiny

E. (A.) monticola Loew

6. $O^{7}$ : fore femur yellowish brown, mid and hind femora black (except yellow subapical part). +: mesonotum greyish with 2 brownish narrow median vittae (dorsal view), halter with dusky yellow knob, wing faintly brownish infuscate on basal part, otherwise hyaline

E. (A.) nitida Meigen

- $\sigma^{7}$ : femora yellow to tawny yellow (sometimes darker towards apex dorsally). : mesonotum velvety brown (dorsal view), halter brown, wing uniformly brown infuscate E. (A.) pachymorion Frey

ACKNOWLEDGMENTS. I am indebted to Andrey Ozerov (ZMMU), Semen Kustov and Vladimir Gladun (KSU) for the loan of specimens used in this study. My special thanks are due to Bradley Sinclair (Canadian National Collection of Insects and Canadian Food Inspection Agency,
Ottawa) for reading the manuscript, remarks and checking the English. Vladimir Neimorovets (All-Russian Institute of Plant Protection, St.-Petersburg — Pushkin, Russia) kindly produced the photo of the new species. This study was performed in the frames of the Russian State Research Project no. AAAA-A17-117030310210-3, the Program of RAS Presidium "Biodiversity of Natural Systems" and supported by the Russian Foundation for Basic Research (grant no. 1504-03457).

\section{References}

Bezzi M. 1909. Einige neue paläarktische Empis-Arten // Deutsche Entomologische Zeitschrift (Beiheft). Bd.1909. S.85-103.

Chvála M. 1994. The Empidoidea (Diptera) of Fennoscandia and Denmark. III. Genus Empis // Fauna Entomologica Scandinavica. Vol.29. P.1-187.

Cumming J.M., Wood D.M. 2009. Adult morphology and terminology // Brown B.V., Borkent A., Cumming J.M., Wood D.M., Zumbado M. (eds.). Manual of Central American Diptera. Vol.1. Ottawa: NRC Research Press. P.9-50.

Shamshev I.V. 2016. An annotated checklist of empidoid flies (Diptera: Empidoidea, except Dolichopodidae) of Russia // Proceedings of the Russian Entomological Society. Vol.87. P.1-184. 